\title{
Jacques de Billy, Six livres du second advenement de nostre Seigneur
}

Michele Mastroianni

\section{(2) OpenEdition}

\section{Journals}

\section{Edizione digitale}

URL: http://journals.openedition.org/studifrancesi/5908

DOI: $10.4000 /$ studifrancesi.5908

ISSN: 2421-5856

\section{Editore}

Rosenberg \& Sellier

\section{Edizione cartacea}

Data di pubblicazione: 1 mai 2011

Paginazione: 158-159

ISSN: 0039-2944

\section{Notizia bibliografica digitale}

Michele Mastroianni, «Jacques de Billy, Six livres du second advenement de nostre Seigneur», Studi

Francesi [Online], 163 (LV | I) | 2011, online dal 30 novembre 2015, consultato il 12 janvier 2021. URL: http://journals.openedition.org/studifrancesi/5908 ; DOI: https://doi.org/10.4000/studifrancesi.5908

Questo documento è stato generato automaticamente il 12 janvier 2021.

\section{(c) (†) $\ominus$}

Studi Francesi è distribuita con Licenza Creative Commons Attribuzione - Non commerciale - Non opere derivate 4.0 Internazionale. 


\title{
Jacques de Billy, Six livres du second advenement de nostre Seigneur
}

\author{
Michele Mastroianni
}

\section{NOTIZIA}

JACQUES DE BILLY, Six livres du second advenement de nostre Seigneur, édition de Thierry VICTORIA, Paris, Éditions Classiques Garnier, 2010 («Textes de la Renaissance», 161), pp. 477.

1 I Six livres du second advenement de nostre Seigneur sono stati pubblicati a Parigi nel 1576: si tratta di un poema epico in alessandrini. Come il titolo stesso indica, l'argomento è escatologico e descrive i novissima. Nel primo libro abbiamo la rappresentazione del mondo corrotto alla fine dei tempi e la venuta dell'Anticristo; il secondo libro evoca i segni escatologici che precedono il giudizio, la Parusia, la resurrezione dei morti e la loro convocazione davanti a Cristo giudice; nel terzo libro abbiamo la sentenza del Giudice nei confronti dei buoni, destinati alla gioia eterna; nel quarto libro la sentenza emessa contro i reprobi; nel quinto la rappresentazione dell'inferno e nel sesto la descrizione della maison de Dieu e dei piaceri paradisiaci. Il poema di Jacques de Billy si inserisce nel gran numero di poemi che testimoniano della diffusione della poesia biblica nel secondo Cinquecento, in particolare della poesia escatologica. L'importanza di questo testo, però, è nel fatto che apre una nuova via, che troverà due anni dopo, nel 1578, una realizzazione maggiore nel grande poema di Du Bartas, quella Sepmaine che offre schemi a tutta l'epica religiosa di fine secolo, ma che trova qui un sicuro, e riuscito antecedente. Le quattro invarianti che definiscono questa categoria di poema (la costatazione della sovversione dei valori morali e spirituali; il racconto dell'avvento dell'Anticristo; la descrizione dei segni escatologici e l'evocazione del Giudizio finale; l'esame dei comportamenti individuali, e soprattutto delle azioni dei grandi di questo mondo, esame che sfocia in una satira sociale) trovano un archetipo completo nell'opera di Jacques de Billy. Thierry Victoria non si limita ad apprestare una buona edizione, puntualmente annotata, ma in un'ampia introduzione (pp. 13-115) offre una 
vera e propria monografia sul genere del poema escatologico e inquadra i Six livres nella tradizione della letteratura patristica e medievale consacrata al tema della fine del mondo. In particolare, illustra come il discorso ecatologico faccia da sustrato a un testo che rispecchia la religiosità di un epoca di profonda crisi, quale fu il secondo Cinquecento. 